\title{
In vitro Anti-Arthritic activity of Pseudarthria viscida against Protein Denaturation and Proteinase enzyme
}

\author{
Research Article
}

\section{Pandian $\mathbf{P}^{1^{*}}$}

1. Department of pharmacy, Annamalai University, Annamalainagar, Tamilnadu, India

\begin{abstract}
Arthritis is an autoimmune with chronic inflammatory, the patient has very painful due deformities and bone erosion which is caused by damage of the joints. The plant Pseudarthria viscida was collected from the Thirunelveli district and extracted with aqueous and ethanol solvent. The two method was used for determination of invitro antiarthritic activity. The Inhibition of Protein Denaturation Method shows the anti-arthritic activity with the value from $40.46 \pm 0.72$ to $78.36 \pm 0.64$ for aqueous extract and $48.62 \pm 0.86$ to $84.42 \pm 0.86$ for ethanol extract and Inhibition of Proteinase Enzyme Activity shows $38.62 \pm 0.32$ to $72.58 \pm 0.58$ in aqueous extract and $46.28 \pm 0.58$ to $80.52 \pm 0.56$ in ethanol extract. Diclofenac sodium were used as standard, the concentration is $100,200,300,400$, and 500. In both the method the concentration of 500Microgram per milliliters shows maximum inhibition and compare to both extract the ethanol shows better activity than aqueous extract.
\end{abstract}

Key Words: Arthritis, Aqueous, Ethanol, Protein, Pseudarthria viscida.

\section{Introduction}

India is widespread of its different geographical and ecological system and also rich in medicinal properties, present in various part of the country. In ancient period of time the medicinal plant is used for various treatment of diseases. WHO state that the primary health care needs of the people depends on traditional medicine in the world. $(1,2)$ Arthritis is an autoimmune with chronic inflammatory, it affects smaller joints, progressing to large joints and along with this skin, eyes, heart, kidneys and lungs also affected. The tendons and ligaments are weakened due to bone and cartilage of joints are destroyed (3) the patient have very painful due deformities and bone erosion which is caused by damage of the joints. The symptoms are referred to stiffness of affected joints, fever, weight loss, joints that are tender, swollen and warm, rheumatoid nodules under the skin and fatigue, the disease start at age between 35 to 60 years with remission and exacerbation. The juvenile RA (JRA) is one affected to the children at the age of 16 years and it is similar to the RA except the rheumatoid factor is not found. (4-7) In the West, the prevalence of RA is believed to be $1-2 \%$ $(7,8)$ and $1 \%$ worldwide. (9) osteoarthritis is the most common effect of arthritis the other effects include gout, fibromyalgia, and rheumatoid arthritis (RA). Some forms of arthritis, such as

\section{* Corresponding Author:}

\section{Pandian $\mathbf{P}$}

Department of pharmacy,

Annamalai university,

Annamalainagar, Tamilnadu, India

Email Id: pandian0071@rediffmail.com rheumatoid arthritis and lupus (SLE), can affect multiple organs and cause widespread symptoms. There are four main groups of drugs used to treat arthritis: Pain killers (analgesics), non-steroidal antiinflammatory drugs (NSAIDs), disease-modifying antirheumatic drugs (DMARDs) and corticosteroids (steroids). (10) In invitro denaturation of proteins there is a production of auto antigens in certain arthritic diseases. (11) There is in alteration of electrostatic, hydrogen, hydrophobic and disulphide bonding in the mechanism of denaturation. (12) the anti-arthritic activity is controlled by the production of auto antigen and inhibiting the denaturation of protein and membrane lysis.

Hence, the anti-protein denaturation and membrane lysis are important measure taken in the invitro anti-arthritic activity. (13) In case of inflammatory and arthritic the denaturation of tissue protein plays a vital role in it for its causes. So, in the arthritic disease the denaturation of protein is responsible for the Production of auto antigen in vivo. Agents that can prevent protein denaturation therefore could be worthwhile for anti-arthritis drug development. (14) There is some protein became antigenic due to formation of denaturation and macroglobulin in the immune response and producing biochemical changes in connective tissue, which Ultimately leads to rheumatoid arthritis. (15)

\section{Materials and Methods}

\section{Ethnobotanical claims of Pseudarthria viscida}

India has about 45,000 species of plant and in this species thousands of species have medicinal properties. The some of the medicinal properties are antidiabetic, antioxidant, anticancer and antiinflammatory etc. these medicinal properties is proved 
by scientifically for their uses. So, it is important for the medicinal plant for its authentication. Research conducted in the last few decades on plants mentioned in ancient literature. Some plants have been demonstrated with animal model for their pharmacological effects, whose active principle have not been isolated and identified.

In some other plants only the biologically active components have been isolated but no pharmacological effects have been described. The use of herbal remedies for arthritis treatment has been gaining momentum in recent years. Roots of medicinal plants are common ingredients of many folk and herbal medicines (16) and extracts of a number of medicinal plants have been reported to possess pharmacological activity, mainly anti-inflammatory activity. Hence an attempt has been made at present work to study the anti-arthritis property, of the Pseudarthria viscida. Pseudarthria viscida (L) Wight is a shrub of family Fabaceae.

The plant is astringent, sweet, bitter, emollient, digestive, constipating, anthelmintic, cardiotonic, febrifuge and tonic. They are useful in vitiated conditions of cough, bronchitis, asthma, tuberculosis, helminthiasis, diarrhoea, inflammation, cardiopathy, fever, haemmorrhoids, gout, diabetes, hyperthermia and general debility. Traditionally this plant is used in the form of decoction or powder for biliousness, excessive heat, intestinal poison, fever, diarrhoea, asthma, heart diseases, worms and pilles. This plant is also used in the preparation of ayurvedic medicines namely Dashamoola, Mahanarayana Taila and Dhantara Taila.

\section{Extraction procedure}

\section{Collection and Processing of Plant material}

The leaf of Pseudarthria viscida was collected in and around of Thirunelveli district. The collected plant material was washed with tap water for 3 times and sterilized by spraying with $70 \%$ alcohol. The sterilized plant material was shade dried at room temperature to avoid chemical changes and frequently observed for any fungal contamination as the plant material rich in water content. When the plant material was completely dried it is subjected to prepare fine powder with the help of pestle and motor. The fine powder is collected and used for extraction of crude drug in aqueous, ethanol solvents by Soxhlet extraction method.

\section{Extraction by Soxhlet apparatus}

The extraction procedure for the isolation of crude drug from plants has been practiced since long time. The precise mode of extraction naturally depends on the texture and water content of the plant material being extracted and on type of substance that is being isolated. Normally the crude extract is taken from soxhlet apparatus with the aqueous solvent. This apparatus mainly consists of three parts, round bottom flask in which the solvent is taken, main jar in which material from which the compounds to be extracted is kept loaded and condenser in which condensation of vapors of solvents takes place. $200 \mathrm{~g}$ of the powder of plant material from which the extract has to be taken is packed into soxhlet main jar. The solvent is poured into the round bottom flask and extract condensation under reduced pressure and controlled temperature of $60-80^{\circ} \mathrm{C}$ is set to boil through regulated heating mantle. The vapor of the solvent pass through drive tubes, enter the condenser through the main jar and get condensed where there is continuous flow of water in the condenser. The condensed solvent falls back on the packed material in the main jar before collecting in jar itself.

The collection and extraction of material takes place simultaneously in the main jar as seen by the coloring of the solvent as compound of material get dissolved in the solvent. The marc is obtained, dried and the dried one is used for the ethanol solvent. Thus, the crude extract of the plant material is obtained and normally it takes 7-8 hours for complete each extraction the solvent will be evaporated and finally it yields green extract, this is stored in refrigerator for further usage.

\section{Evaluation of anti-arthritic activity}

Anti-arthritic activity was evaluated through Inhibition of protein denaturation method and Inhibition of proteinase enzyme activity. Diclofenac sodium was the standard drug used. Each experiment was done in triplicates and the average percentage of inhibition was calculated from the three results.

\section{Inhibition of Protein Denaturation Method (17)}

Protein Denaturation Method was carried out as per standard procedure using Bovine serum albumin.

- Test solution: $0.5 \mathrm{ml}$ of Pseudarthria viscida extract and $0.45 \mathrm{ml}$ of bovine serum albumin

- Test control solution: $0.45 \mathrm{ml}$ of bovine serum albumin and $0.5 \mathrm{ml}$ of distilled water

- Product control solution: $0.45 \mathrm{ml}$ of distilled water and $0.5 \mathrm{ml}$ Pseudarthria viscida extract

- Standard solution: $0.45 \mathrm{ml}$ of bovine serum albumin and $0.5 \mathrm{ml}$ of Diclofenac Sodium

All the sample solutions were incubated at $37^{\circ} \mathrm{C}$ for 20 minutes. Temperature was increased to $57^{\circ} \mathrm{C}$ for 3 minutes. It was then allowed to cool for some time and $2.5 \mathrm{ml}$ of phosphate buffer was added to all the above solutions. The absorbance of resulting solution was measured at $416 \mathrm{~nm}$ using UV visible spectrophotometer. The percentage of inhibition Pseudarthria viscida extract. was calculated using the following formula:

Percentage of Inhibition $=100-\{$ (optical density of test solution - optical density of product control)/ optical density of test control $\} \times 100$

Inhibition of Proteinase Enzyme Activity (18)

As per standard procedure, the proteinase enzyme used was trypsin.

- Test solution: Phosphate buffer $+1 \mathrm{ml}$ Tris Hydrochloric acid + trypsin $+1 \mathrm{ml}$ Pseudarthria viscida extract 
- Test control solution: Phosphate buffer+1ml Tris Hydrochloric acid

- Product control solution: Phosphate buffer $+1 \mathrm{ml}$ Tris Hydrochloric acid $+1 \mathrm{ml}$ Pseudarthria viscida extract Standard solution: Phosphate buffet $+1 \mathrm{ml}$ Tris Hydrochloric acid + trypsin $+1 \mathrm{ml}$ Diclofenac sodium.

The reaction mixture contained $0.06 \mathrm{mg}$ trypsin. $1.0 \mathrm{ml}$ of $25 \mathrm{~mm}$ Tris Hydrochloric acid buffer $(\mathrm{pH} 7.4)$ and $1.0 \mathrm{ml}$ aqueous solution of test sample were incubated at $37^{\circ} \mathrm{C}$ for 5 minutes. Then $1.0 \mathrm{ml}$ of $0.8 \%$ $(\mathrm{w} / \mathrm{v})$ Casein was added and incubated for 20 minutes. $2.0 \mathrm{ml}$ of $70 \%(\mathrm{v} / \mathrm{v})$ Perchloric acid was added to terminate the reaction. The cloudy suspension was centrifuged. Optical density of supernatant was read at $280 \mathrm{~nm}$ against buffer as blank. The percentage of inhibition was calculated using the formula.

Percentage of inhibition $=100-\{$ (Absorbance of test solution- Absorbance of product control)/ Absorbance of test Control $\} \times 100$

\section{Result and discussion}

The inhibition of protein denaturation method for Pseudarthria viscida was determined by various concentrations such as $100,200,300,400,500$ and the plant percentage inhibition was done with aqueous extract and ethanol extract. The percentage inhibition of protein denaturation with various concentrations shows the different values such as from $40.46 \pm 0.72$ to $78.36 \pm 0.64$ and it is compared with the standard diclofenac sodium the comparison shows the percentage inhibition for the concentration of $500 \mu \mathrm{g} / \mathrm{ml}$ shows maximum inhibition in aqueous extract and in standard respectively. In ethanol extract was same as previous one which shows the values from $48.62 \pm 0.86$ to $84.42 \pm 0.86$ and also the maximum inhibition was at concentration of $500 \mu \mathrm{g} / \mathrm{ml}$ in table-I. In comparison with both extract the ethanol shows the maximum inhibition activity when compare to aqueous extract.

In inhibition of proteinase enzyme activity method for Pseudarthria viscida was determined by various concentrations such as $100,200,300,400,500$ and the plant percentage inhibition was done with aqueous extract and ethanol extract. The percentage inhibition of proteinase enzyme activity with various concentrations shows the different values such as from $38.62 \pm 0.32$ to $72.58 \pm 0.58$ and it is compared with the standard diclofenac sodium the comparison shows the percentage inhibition for the concentration of $500 \mu \mathrm{g} / \mathrm{ml}$ shows maximum inhibition in aqueous extract and in standard respectively. In ethanol extract was same as previous one which shows the values from $46.28 \pm 0.58$ to $80.52 \pm 0.56$ and also the maximum inhibition was at concentration of $500 \mu \mathrm{g} / \mathrm{ml}$ in table-II. In comparison with both extract the ethanol shows the maximum inhibition activity when compare to aqueous extract.
Table1: Inhibition of Protein Denaturation Method for Pseudarthria viscida

\begin{tabular}{|l|l|l|l|}
\hline $\begin{array}{l}\text { Conc }(\boldsymbol{\mu g} / \\
\text { ml) }\end{array}$ & $\begin{array}{l}\text { \%inhibition } \\
\text { of protein } \\
\text { denaturatio } \\
\text { n method } \\
\text { for aqueous } \\
\text { extract }\end{array}$ & $\begin{array}{l}\text { \%inhibition } \\
\text { of protein } \\
\text { denaturatio } \\
\text { n method } \\
\text { for ethanol } \\
\text { extract }\end{array}$ & $\begin{array}{l}\text { \%inhibition } \\
\text { of protein } \\
\text { denaturatio } \\
\text { n method } \\
\text { for } \\
\text { standard } \\
\text { (Diclofenac) }\end{array}$ \\
\hline 100 & $40.46 \pm 0.72$ & $48.62 \pm 0.86$ & $80.65 \pm 0.36$ \\
\hline 200 & $48.28 \pm 0.58$ & $56.24 \pm 1.24$ & $86.48 \pm 0.84$ \\
\hline 300 & $56.32 \pm 1.08$ & $64.58 \pm 0.56$ & $90.08 \pm 0.24$ \\
\hline 400 & $65.58 \pm 0.12$ & $72.68 \pm 0.32$ & $94.62 \pm 0.76$ \\
\hline 500 & $78.36 \pm 0.64$ & $84.42 \pm 0.86$ & $98.86 \pm 0.52$ \\
\hline
\end{tabular}

Each value was obtained by calculating the average of three determinants and data are presented as mean \pm SEM

Table 2: Inhibition of Proteinase Enzyme Activity for Pseudarthria viscida

\begin{tabular}{|c|c|c|c|}
\hline $\begin{array}{l}\text { Conc }(\mu \mathrm{g} / \\
\mathrm{ml})\end{array}$ & $\begin{array}{l}\% \\
\text { Inhibition } \\
\text { of } \\
\text { Proteinase } \\
\text { Enzyme } \\
\text { Activity for } \\
\text { aqueous } \\
\text { extract }\end{array}$ & $\begin{array}{l}\% \\
\text { Inhibition } \\
\text { of } \\
\text { Proteinase } \\
\text { Enzyme } \\
\text { Activity for } \\
\text { ethanol } \\
\text { extract }\end{array}$ & $\begin{array}{l}\% \\
\text { Inhibition } \\
\text { of } \\
\text { Proteinase } \\
\text { Enzyme } \\
\text { Activity for } \\
\text { standard } \\
\text { (Diclofenac) }\end{array}$ \\
\hline 100 & $38.62 \pm 0.32$ & $46.28 \pm 0.58$ & $82.64 \pm 0.65$ \\
\hline 200 & $46.84 \pm 0.68$ & $58.68 \pm 0.28$ & $88.52 \pm 0.58$ \\
\hline 300 & $52.36 \pm 0.84$ & $63.48 \pm 1.38$ & $92.36 \pm 0.24$ \\
\hline 400 & $64.36 \pm 0.24$ & $70.62 \pm 0.92$ & $96.32 \pm 0.52$ \\
\hline 500 & $72.58 \pm 0.58$ & $80.52 \pm 0.56$ & $99.42 \pm 0.68$ \\
\hline
\end{tabular}

Each value was obtained by calculating the average of three determinants and data are presented as mean \pm SEM

Figure1: Inhibition of Protein Denaturation Method for Pseudarthria viscida

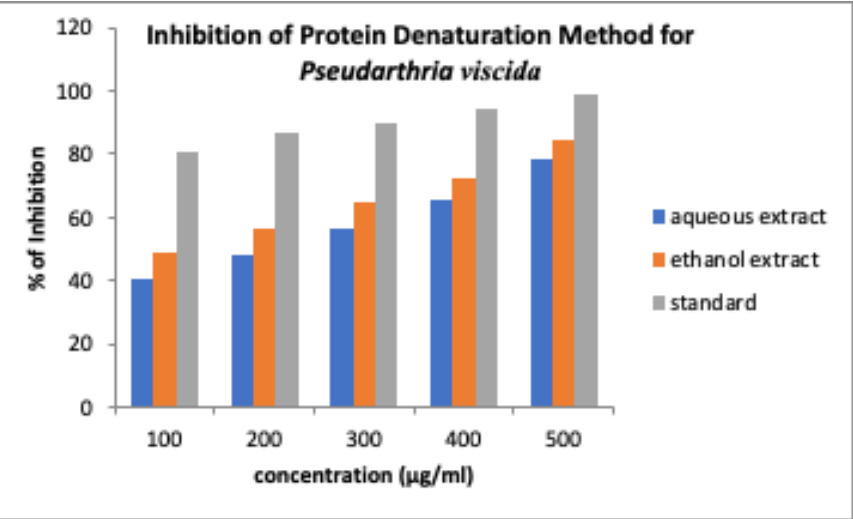


Figure 2 Inhibition of Proteinase Enzyme Activity for Pseudarthria viscida

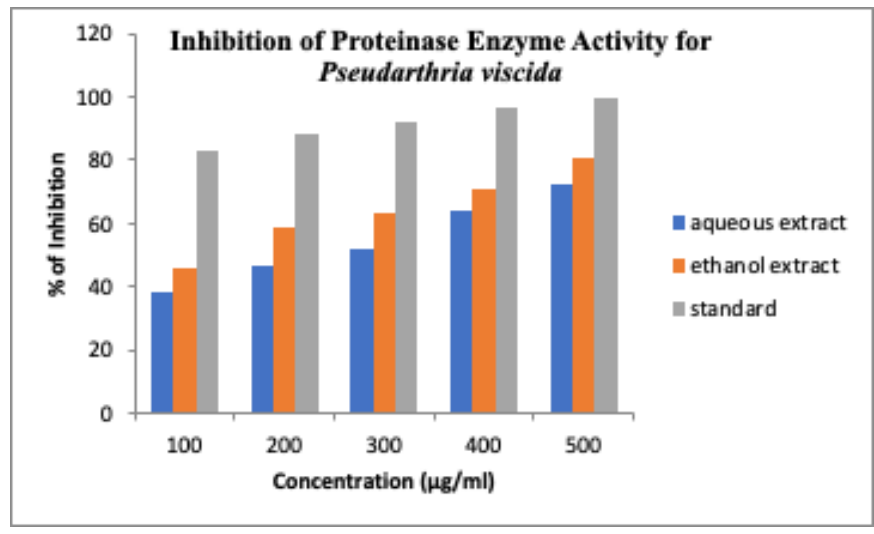

In the arthritis disease, the denaturation of protein, membrane lysis and proteinase action are due to the production of auto antigen the mechanism of denaturation probably involves electrostatic hydrogen, hydrophobic and disulphide bonding. From the results the maximum percentage inhibition of protein denaturation of extract and standard were observed fromTable.1 and from Figure 1. In the bovine serum albumin (BSA) there are two interesting binding site namely aromatic tyrosine rich and aliphatic threonine and lysine residue are responsible for the antidenaturation property of BSA as per the literature. (19) It has been reported that the receptor rich in tyrosine motif which is a therapeutic molecule for activating the threonine signal transduction biological pathway for their overall biological action. $(19,20)$ Compounds interacting with the aliphatic regions around the lysine residue on the BSA could be interesting as anti-oxidant with anticancer activity such as the polyphenols, phenyl propanoids and the disulphides. (19-22) However the extract is phenolic in nature, as per the literature. Hence this may be the region for its possible anti-denaturation activity. It seems that the presence of protease inhibitors at the site of arthritic, first shown by Opie. (23) is important in limiting the destructive activity of proteases that are liberated from polymorphonuclear leucocytes and other necrotizing tissues. At least two such enzymes have been isolated and characterized. (24, 25 ) It would be interesting to know which proteases are present as inhibitor complexes and which remain uninhibited; for proteases that are not inactivated should be potentially more destructive ones. The inhibition of these proteases by other normally occurring inhibitors as well as synthetic ones could be an important step in preventing tissue damage in arthritis and as per the result the extract and standard shows the maximum Inhibition of Proteinase enzyme activity were observed in table II and figure II The investigation had clearly demonstrated that the Pseudarthria viscida possess potent anti-denaturation property and anti-proteinase enzyme activity. The phenolic nature of the Pseudarthria viscida may be the region for its possible anti-arthritis activity. Further in-vivo studies have performed to authenticate anti-arthritic activity.

\section{References}

1. Gautam RK, Ulcer protective action of Punica granatum Linn. in aspirin induced ulcer in diabetic rats. Journal of Pharmacy Research. 2012; 5(8); 4389-4391

2. Kosalge SB, Fursule RA, Investigation of ethano medicinal claims of some plants used by tribals of Satpura Hills in India. Journal of Ethnopharmacology. 2009; 121; 456-461

3. Lee JE, Kim IJ, Cho MS, Lee J A Case of Rheumatoid Vasculitis Involving Hepatic Artery in Early Rheumatoid Arthritis. Journal of Korean Medical Sciences. July,2017; 32(7); 1207-1210

4. Fox CQ, Ahmed SS, Physician Assistant's Clinical Review Cards. 3rd edition. Philadelphia; F. A. Davis Company; 2002. 138-139p.

5. McInnes IB, Schett G, The pathogenesis of rheumatoid arthritis. New England Journal of Medical. December, 2011; 365(23);2205-2219

6. Chaudhari K, Rizvi S, Syed BA, Rheumatoid arthritis: current and future trends. Nature Review in Drug Discovery. May, 2016;15(5); 305-306

7. Picerno V, Ferro F, Adinolfi A, Valentini E, Tani C, Alunno A. One year in review: the pathogenesis of rheumatoid arthritis. Clinical Experimental in Rheumatology. July, 2015; 33(4);551-558

8. Alamanos Y, Voulgari PV, Drosos AA, Incidence and prevalence of rheumatoid arthritis, based on the 1987 American College of Rheumatology criteria: a systematic review. Seminar Arthritis Rheumatology. December, 2006; 36(3);182-188

9. Chopra A, Abdel-Nasser A, Epidemiology of rheumatic musculoskeletal disorders in the developing world. Best Practical Research in Clinical Rheumatology. August,2008 ;22(4); 583604

10. Sunetra K Patwardhan, Kaumundee S Bodas, Sameer S Gundewar. Copying with arthritics using safer herbal options, International Journal of Pharmacy and Pharmaceutical Science. 2010;2(1);1-11

11. Brown $\mathrm{J} \mathrm{H}$ and Mackey $\mathrm{H}$ K, Inhibition of heat induced denaturation of serum proteins by mixture of non-steroidal anti-inflammatory agents and amino acids, Proceeding in Social Experimental Biology Medicine. 1968; 128(1); 225-228

12. Grant N H, Alburn H E, Kryzanauskas C. Stabilisation of serum albumin by antiinflammatory drugs, Biochemistry and Pharmacology. 1970; 19(3); 715

13. Sharan, Suresh Volluri, Srinivasa Rao Bammidi, Seema Chaitanya Chippada and Meena Vangalapati. In-Vitro Anti-Arthritic Activity of Methanolic Extract of Bacopa Monniera, International Journal of Chemistry Environmental and Pharma Research. $2011 ; 2 ; 1-3$

14. Thomas, LL, David, AW, Victoria, FR \& William, Foye's Principle of Medicinal Chemistry, Wolters Kluwer, Lipincott William \& Wilkin, 2013. 1024p.

15. Roberts, RC, Reisen, WA \& Hall, PK, 'On the quaternary structure of human serum a2- 
macroglobulin', in Proteinase Inhibitors. 3ed. New York; E Springer-Verlag, , 1974. 63-71p.

16. Solomon Habtemariam., Anti-inflammatory activity of the antirheumatic herbal drug, gravel root (Eupatorium purpureum): Further biological activities and constituents. Phyto therapy Research. December, 2001; 15(8); 687-690

17. Singh M, Soni P, Upmanyu N, Shivhare Y, In-vitro Anti-arthritic Activity of Manil karazapota Linn, Asian Pharma Press. 2011;1(4);123-124

18. Trivedi R, Srivastava DN, Sharma S, Anti-arthritic Activity of Methanolic Extract and Various Fractions of Trigonella foenum-graecum Seed: An In-vitro Study. International Journal of Pharmaceutical \& Biological Archives. 2015; 6(6); $32-36$

19. Williams LAD, Connar AO, Latore 1, Dennis O,Ringer S, Whittaker JA, Conard J, Vogler B, Rosner H, Kraus W, The in vitro anti denaturation effects induced by natural products and nonsteroidal compounds in heat treated (immunogenic)bovine serum albumin is proposed as a screening assay for the detection of antiinflammatory 226 compounds, without the use of animals, in the early stages of the drug discovery process, West Indian Medical Journal. 2008; 57; 327-331
20. Rosner H, Williams LAD, Jung A, Kraus W, Disassembly of microtubules and inhibition of neurite out growth, neuroblastoma cell proliferation and MAP kinse tyrosine dephosphorylation by dibenzyl trisulphide, Biochemistry and Biophysics Acta. 2001; 1540; 166-177

21. Kannan S, Free radical theory of autoimmunity, Theory of Biological in Medical Model. 2006; 3; 22.

22. Kawabata T, Packer L, $\alpha$ - lipoate can protect against glycation of serum albumins but not low-density lipoproteins, Biochemistry Biophysics and Research Communication. 1994; 203; 99- 104

23. Opie E. L, and Barker B. I, Leucoprotease and antileucoprotease of mammals and of birds, Journal of experimental Medicine. 1907; 9; 207

24. Janoff, A and Scherer J, Mediators of inflammation in leukocyte lysosomes. IX. Elastinolytic activity in granules of human polymorphonuclear leukocytes, Journal of experimental Medicine. 1968; 128; 1137

25. Lazarus G. S, Daniels J. R, Brown R. S, Bladen H. A, and Fullmer H. M, Degradation of collagen by a human granulocyte collagenolytic system, Journal of clinical Investigation. 1968; 47; 2622 